\title{
A Lesson of Sustainability Given by The Tropical Modernism in Kinshasa: The BCB Headquarters by Maurice Houyoux
}

\author{
Manlio Michieletto ${ }^{1}$, Olatunde Adedayo ${ }^{1} \&$ Alexis Tshiunza $^{2}$ \\ ${ }^{1}$ School of Architecture and Built Environment, University of Rwanda, Kigali, Rwanda \\ ${ }^{2}$ School of Architecture and Urban Planning, Kinshasa, DR Congo \\ Correspondence: Manlio Michieletto, School of Architecture and Built Environment, University of Rwanda, \\ Kigali, Rwanda. Tel: 250-782-331-016.
}

Received: February 7, 2021 Accepted: February 17, 2021 Online Published: February 20, 2021

\begin{abstract}
The tropical region is often considered as a region where the sun shines intensely and the temperature varies at certain times of the year. In the case of Congo, the average weather condition is considered cool, however, there have been cases where the temperature reached up to $43^{\circ} \mathrm{C}$. It is therefore imperative for buildings in this region to take into account the temperature variation while considering the comfort of the users. During the design and construction of the Bank of Belgian Congo, the availability of data to assist the architect Maurice Houyoux in meeting the challenge of the region was unavailable. The architect had to be creative in planning and overcoming the challenges posed by the environment. This paper seeks to examine the issues confronted by Maurice Houyoux and the design solutions he provided to ensure that the building was functional and responded to the tropical challenges. In undertaking this study, a historical approach was adopted through the review of relevant literature on the building and designs within the period of the development of the bank. An observation method was also deployed to verify some of the information found in the literature. The findings are presented using pictures and sketches to explain some of the key issues relevant to the design of the bank. The findings showed that despite the reduced number of published data for designing in such a region, the architect was able to examine the existing buildings and discuss with users of other constructions to obtain relevant data. The findings also showed that the building was able to respond to peculiar requirements to be functional. The paper concludes that the local building materials and traditional builders can be used to achieve a contemporary building that fits into the context towards sustainable architecture.
\end{abstract}

Keywords: Kinshasa, tropical architecture, tropical modernism, sustainability

\section{Introduction}

\subsection{The Belgian Congo}

The end of the Second World War brought about an era where the overall situation and conditions improved considerably in Belgian colonies boosting the construction sector. Congo though not considered a resettlement colony had the construction of various buildings planned for it, a good example was the Forescom in 1946 - see Fig. 1. The Forescom building showed the possibility to construct upon sandy soil and essentially using the local manpower. The trend of using the methods employed in the construction of Forescom building has witnessed a change; with the reproduction of bungalows, the tendency to build with metal elements, and the introduction of arcades which has generally been taken over by architectural concepts. Several reasons had been adjudged for the change however the most significant reason has been the presence of young architects from Belgium; most of whom were engaged in the Belgian companies that wanted to invest in Congo. One of these young architects was Maurice Houyoux, who worked for the Bank of Belgian Congo and for the Trade and Industry which was one of the first and biggest foreign companies in the colony. After the Government voted a ten-year plan to develop the colony and many projects were realized to transform the country into a colony model and make the capital city, Leopoldville, a "Grand Leo (Big Leo)". This capital city was to become finally "Kin-la-belle" through a specific and characteristic architecture: tropical modernism.

A ten-year plan geared towards economic expansion was launched in 1949 by the Colonies' Ministry to improve the standard of living of the population. The expected budget for the urban planning and the new public buildings was spectacular compared to the one of 1949 , it went from 1.2 billion or $4.7 \%$ up to 7.6 billion or $16 \%$. The new Government explained, that Congo was getting "in the way of important and multiple achievements" that "included 
town planning for healthy urban planning, large-scale construction of housing for Europeans, public buildings, schools, hospitals, and clinics. The general overhaul of the Congolese cities and the gradual replacement of existing rammed houses with houses made out of permanent materials" to modify "in a remarkable way the aspect of our Congolese agglomerations" (Jungers, 1950). The creation of the "African Cities Office (OCA)" in charge of the modern cities' construction was a great achievement. The public and private enterprises acquired new infrastructure. The construction of a new headquarters for the Bank of Belgian Congo was to participate in this image of "Grand Leo".

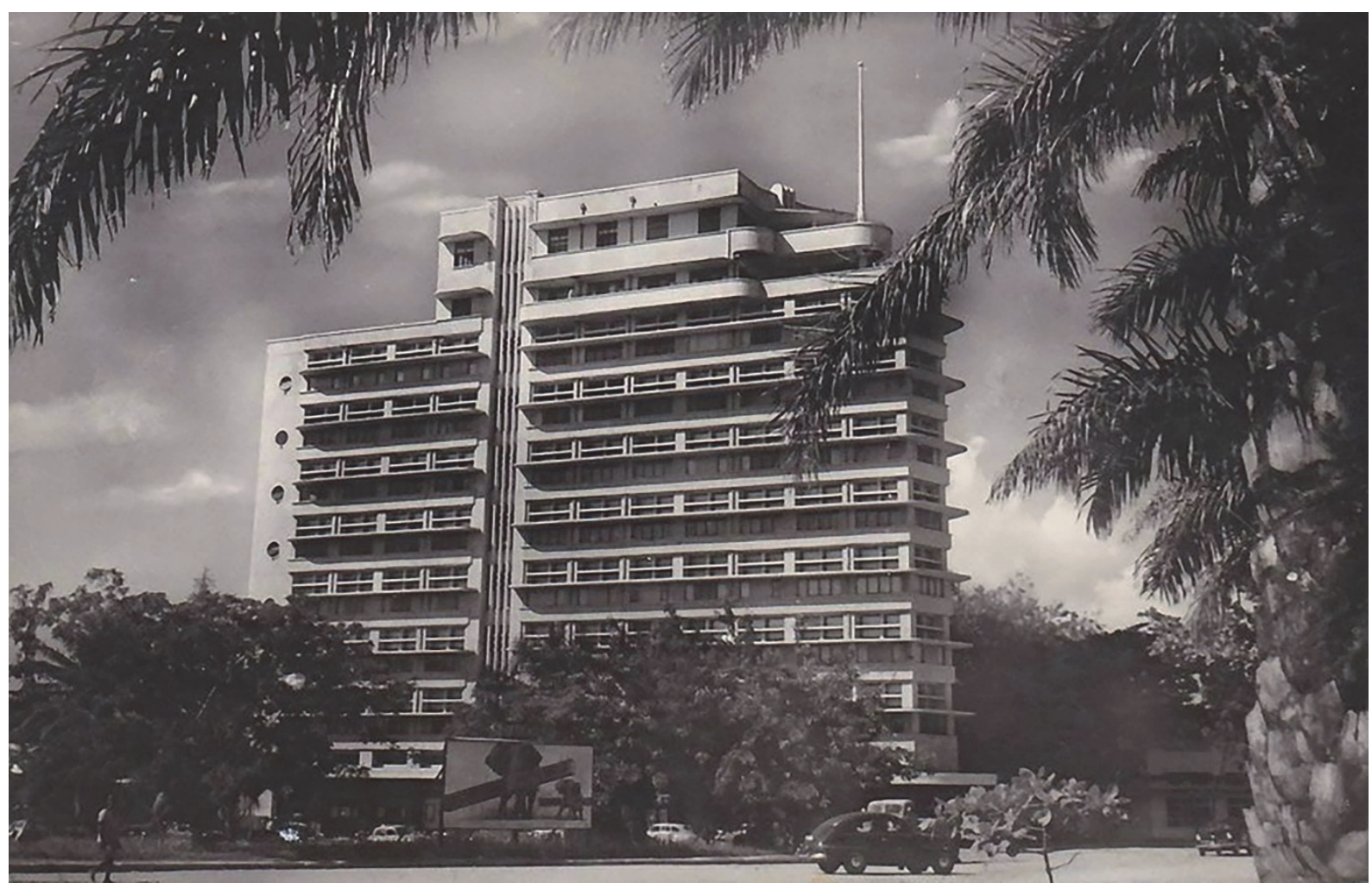

Figure 1. Forescom Building in Kinshasa, 1946. Source: www.delcampe.be

\subsection{The Bank of Belgian Congo}

The Bank of Belgian Congo was founded in 1909 in the city of Matadi, and two years later it obtained the status of issuing bank and began printing banknotes. Belgium found this privilege too critical for a private company and therefore, the Bank ceded this responsibility to the State and became a private credit institution in 1952. From the opening of the Kinshasa headquarters in 1915 up to the moment when Leopoldville became effectively the capital city, the Bank had operated in a building built according to the colonial style. It was during the 1940s' that the project to build a new bank was launched. The new headquarters was to replace that of 1915 depicted in Fig. 2 . The new bank headquarters project had to foresee the accommodations for the officials in addition to the office spaces, as shown in Fig. 3. The bank headquarters was called Bank of Congo after the Independence, and during the Mobutu Realm Commercial Bank of Zaire and now Commercial Bank of Congo. The bank still exists, but the building is currently being used as the office of the Portfolio Minister, as shown in Fig. 15. 


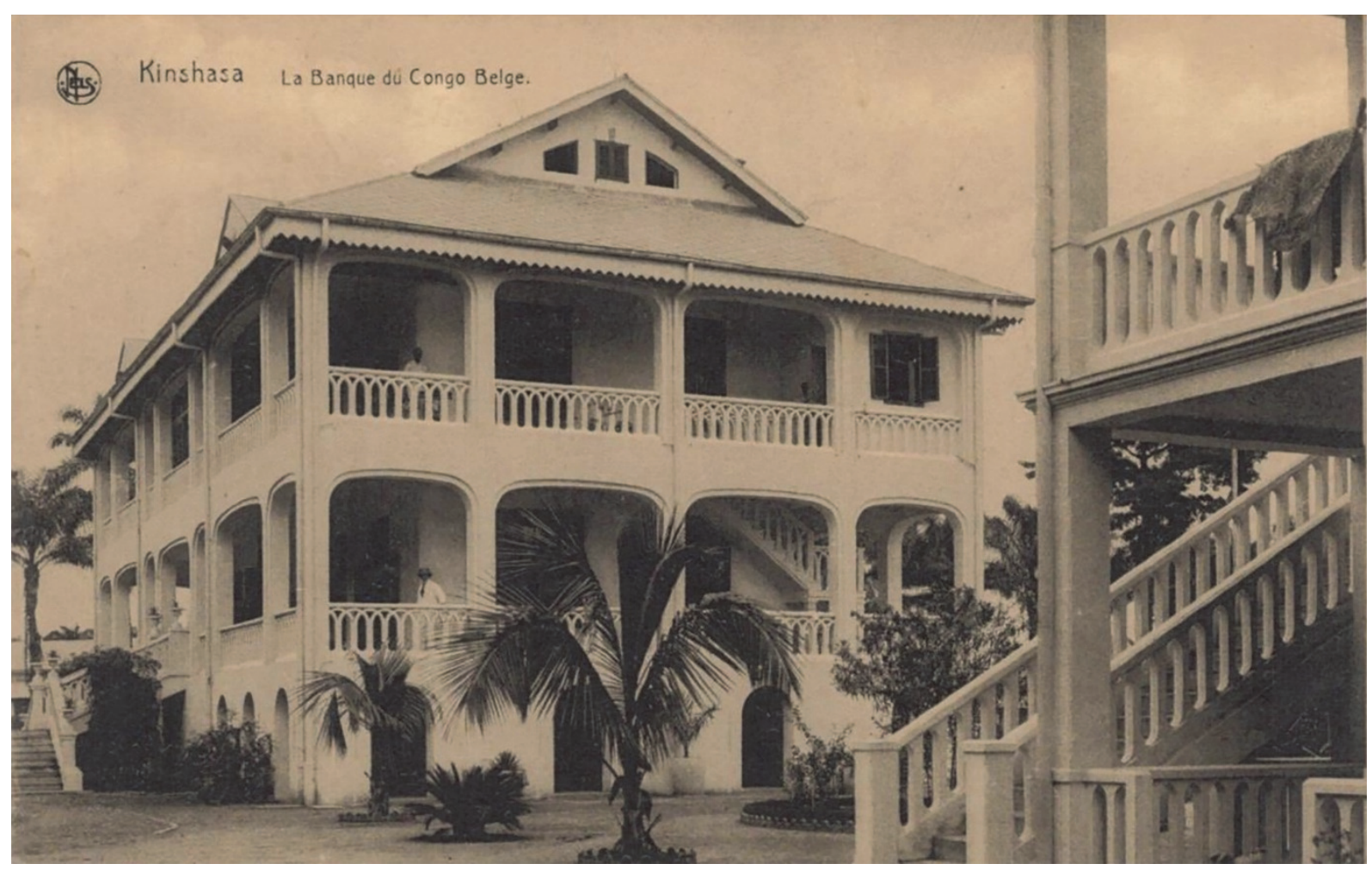

Figure 2. Belgian Bank of Congo, 1915. Source: www.delcampe.be

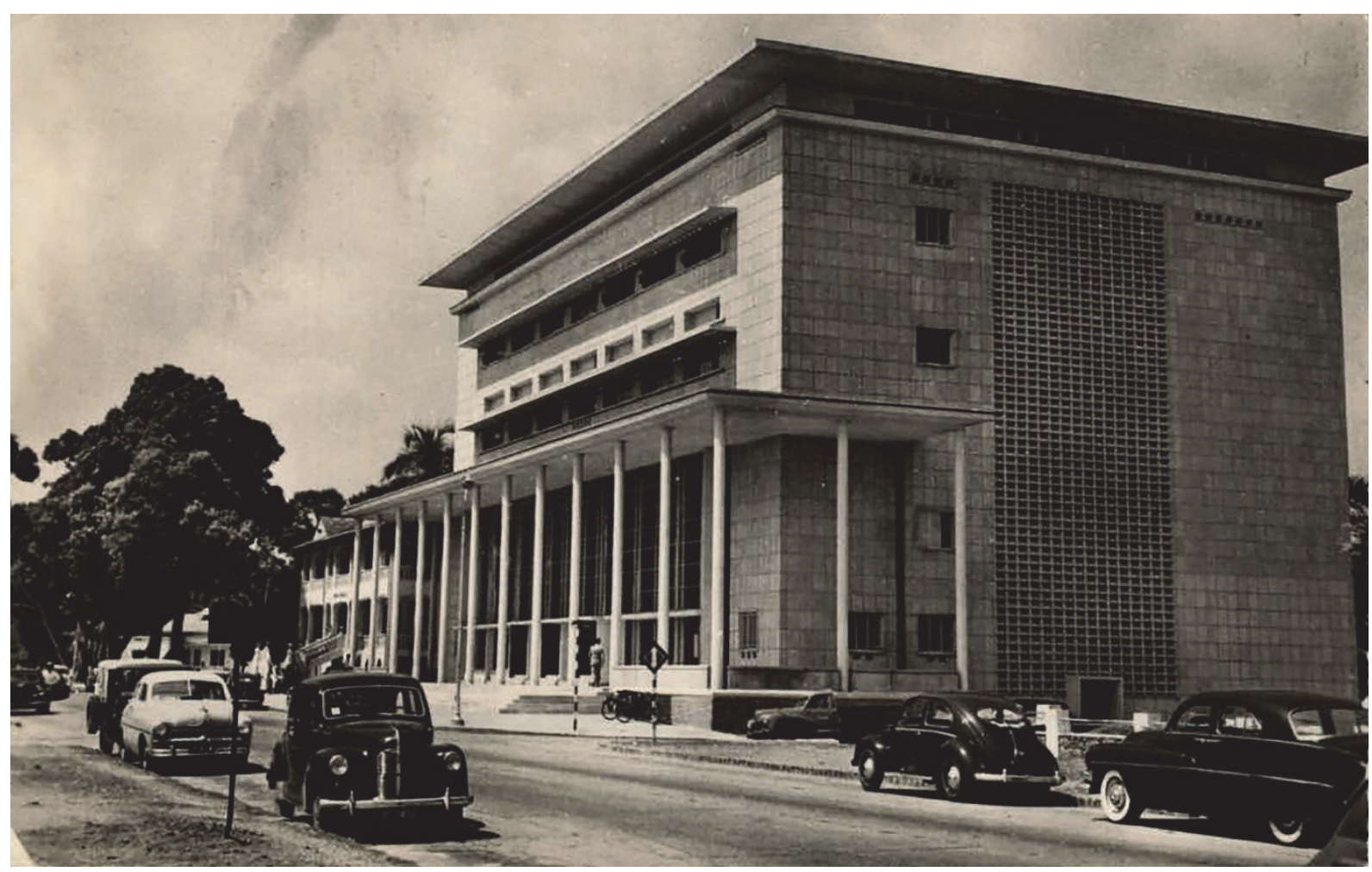

Figure 3. Belgian Bank of Congo, 1950. Source: www.delcampe.be 


\subsection{The Houyoux's Architectural Method}

Maurice Houyoux arrived in Congo during the launching of the decennary plan among a host of other young architects who had come to start, promote or extend their career. Upon arrival, there were not many examples to draw inspiration from, but over time there has been some improvement. The Belgian architect is well known in Congo for the high number of projects he realised, among which are the building for the Company of Congo for Commerce and Industry (CCCI) and the headquarters of Belgian Congo Bank. The Royal Library "Albert the 1st" in Bruxelles is considered the most important work which was not completed during his lifetime. A large number of sketches and drawings on the project modifications had been done to better adapt the concept to the context and the closest building. This monumental work allows one to understand the extent to which Houyoux considered the local context in the African projects. The delay caused by the site change for the Royal Library gave him the chance to be more focused on the construction of different projects in Congo, including housing and banks. He also took part in the creation of the journal Rythme; thus, through it, references may be found with which to understand the relationship Houyoux had with Africa, specifically the Belgian Congo. The progress known in the knowledge on tropical architecture makes it a feature not only functionalist as in the era of the hygienist architecture but also as a new aesthetic. Houyoux in this field is among the pioneers in Congo and even in Africa if we consider that the first African project of Fry and Drew dates from the same time.

\subsection{The Tropical Modernism}

The tropical architecture approach is characterized by the observance of few and simple principles that are typical even in the Rwandan artefacts of the first half of the XX century as well as in the contemporary ones. The first step is to accurately study the site providing the correct orientation to the building. To Orient, the word means "to indicate the east", and east derives from the Latin Oriente, and indicates the direction from which the sun rises during the equinoxes. Light comes from the East, therefore; the orientation is closely connected with the position of the sun from the very be- ginning of Architecture. In Tropical Africa, the question of the orientation of the building is a determining factor for thermal comfort, and normally it's preferable to privilege the arrangement of the different spaces of the house along the east-west axis with the north and south facades less exposed to the direct solar radiation. Another important factor in orienting the building is the distance from the equator, which is a fundamental factor for knowing the inclination of the sun during the day and thus, providing the house with appropriate protective devices. The walls facing east and west, which are sunny in the morning and afternoon respectively, must be also protected and insulated so that the heat is not transmitted into the building. The roof, which is mostly exposed to the sun during the day, must be able to reflect the heat, and adequate spacing between the roof and the ceiling so that it can be constantly ventilated. For the roof covering the use of materials with high inertia, for example, tiles of local manufactured, or poor conductive capacity, such as corrugated aluminum, are to be preferred for zenithal protection. In tropical humid climates, it is advisable to place buildings in such a way as to exploit the prevailing winds as a natural resource capable of transversely ventilating the interior spaces. The shape, size, and position of the openings are also key items to be taken into consideration during the design phase. Building materials are normally local stone, clay, and wood with the addition of reinforced concrete. The tropical decorative apparatus consists of those architectural elements peculiar of the modern language that are adapted to the context: the cantilevered roof to increase the protection of the facade, the vertical or horizontal slabs (brisesoleil), the perforated walls, the ventilated façade, the raised frames to protect the openings, the different air intakes and often the use of arcades or barza. These components are obsessively repeated in a sort of rational mannerism capable of harmoniously linking the strategies for placing the project with the existing environment.

\section{Method}

The study falls under the category of historical research because of the historical data that was used, which was sourced from literature in form of books, journals, and archival records. The literature was sourced from libraries, establishments charged with record-keeping in Congo, and journal websites. The findings in the literature were further confirmed through the direct observation of the case study. The Bank of Belgian Congo was selected as a case study because it was one of the significant buildings executed by Houyoux. The headquarters of the bank is located in the capital city in the district of Gombe, the business centre, on the Wagenia Road not far from the Congo River and continuation of Lumpungu Road as shown in Fig. 4. The specific considerations made to counter the effects of the weather in the tropics and the cultural requirements of the traditional architecture of Congo were noted. The findings and discussions are presented in specific subheadings, while pictures and sketches were used to represent some of the findings to help further explain the issues and solutions adopted in the design and construction of the bank. 


\section{Results}

\subsection{Tropical Modernism in Kinshasa (Leopoldville)}

Tropical architecture would be one that meets a set of categorical imperatives including sun, heat, wind, and rain (Houyoux-Diongre, 1955). An architectural movement can be defined as "general characteristics of a particular time and place arising from available materials and technical resources" (Raeburn, 1982). Houyoux believed that tropical cities, Congolese cities, in particular, would find their beauty, their character, their personality, or their style finally (Houyoux-Diongre, 1955). He had no fear that by doing this, his buildings would lack beauty. On the contrary, "the climate, the use, the respect of the technique defines the architectural morphology with the greatest chance of agreeing to an aesthetic expression" (Puttemans, 1960). The Bank of Belgian Congo headquarters as already established in the literature review section of the paper was constructed as part of a response towards making the colony a grand city based on the desire of the head of Government at that period. It is worthy of note that when the bank headquarters was conceived and constructed there was little data available for designing in the tropics. The various design considerations undertaken by Houyoux are presented under selected subheadings in this section.

\subsection{Orientation of the Building and Site Selection}

The Congo River is an important landmark in the Democratic Republic of Congo, although a railway has been built to connect the Ocean with Kinshasa, thus by-passing the non-navigable part of the river. The first commercial building for the port followed this implantation. In 1915 the Bank of Belgian Congo was looking for a site in Kinshasa and they found it in Hauzeur Street - now called Wagenia, which was considered as the right place for the new headquarters. This goes to show that the selection of the site was such the architect wanted the building to be visible to everyone who came to the city and also to symbolize the power of the bank. The choice of the site also ensured that access to the bank was easy and the building access was not limited by the access road. The location also ensured that the building could be used to serve as a focal point within the city as seen in Fig. 4 and Fig. 5. The chosen site for the construction of the new headquarter of the Bank was one of the most requested after the relocation of the railway.

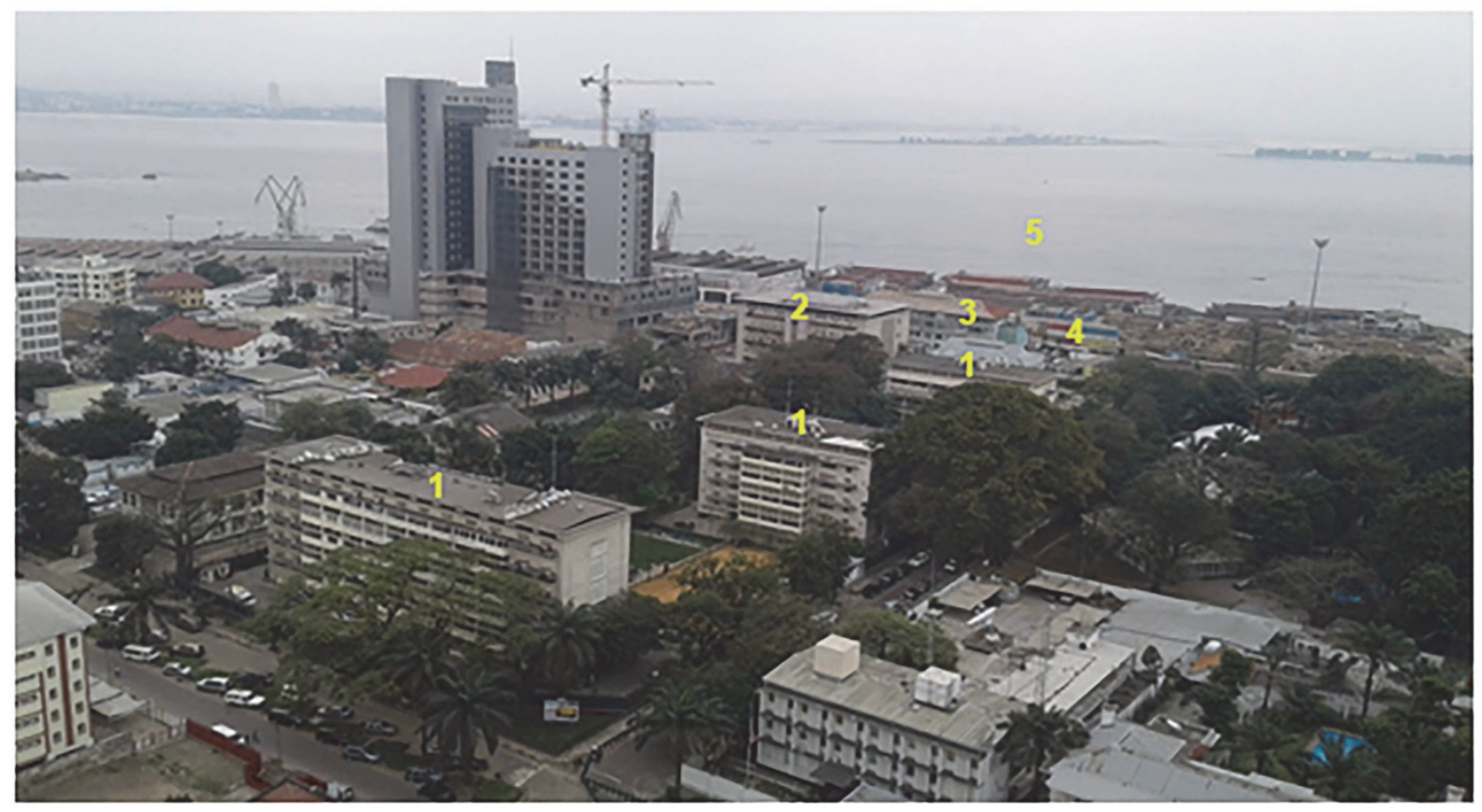

Figure 4. Aerial view of the BCB complex. Legend: 1. Public servants' housing; 2. Belgian Congo Bank (BCB) Headquarters; 3. ABC Hotel 4. Harbour "Beach"; 5. Congo river. Source: picture by Tshiunza Alexis (2020) 


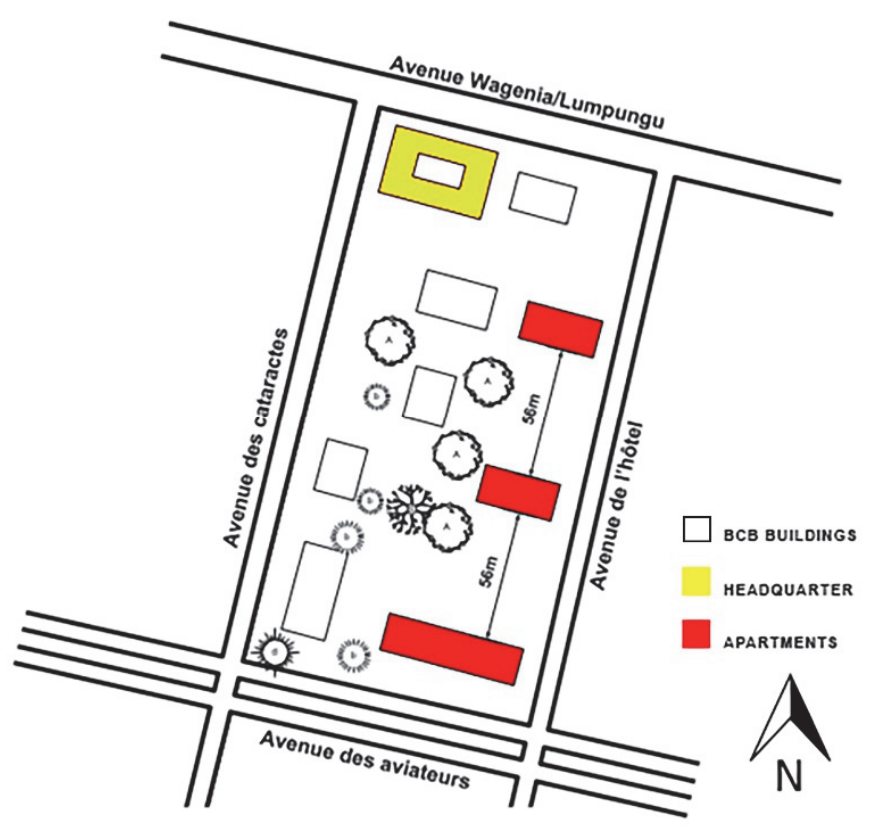

Figure 5. Buildings of BCB: The Headquarters on Wagenia Street and the apartments perpendicular to Hotel Street. Source: drawing by Alexis Tshiunza (2020)

\subsection{Architectural Context Consideration}

In attempting to realize a convenient Architecture for Congo, Houyoux had to either count on what existed on-site or come up with an innovation. In this case, the critical point of view prevailed because he decided the extent to which the building was to be integrated into the built environment or the extent to which it would be unique. The site was surrounded by the building of the former "ABC Hotel" which was the assembly point of all Europeans since 1914, the building of the former "Stanley Hotel", the former "Bingo Casino" which all offered some form of architectural style for the architect to either copy or draw inspiration from. The architect did not copy the form or expression of these buildings, as there is also no imitation of the colonial-style bank built-in 1915. One can understand why, when he realized the project in Leopoldville in 1949, there were still few articles on the climate, such as "Living conditions and physical factors to which dwellings in the Belgian Congo must respond" (Devroey, 1949), "Protections against solar rays" (Van Loo, 1949) or "Building in the tropics" (Atkinson, 1950) which appeared in pages of review Rythme.

\subsection{Climate of Congo as Considered for the Design}

The hot and humid climate is characterized by an average temperature from $20^{\circ} \mathrm{C}$ up to $35^{\circ} \mathrm{C}$, with a relative humidity superior to $55 \%$. It is the mix of humidity and warmth that makes this climate uncomfortable, the basic principles for building in the tropics are the same: a) reducing the direct sunlight; b) natural ventilation; c) natural lighting; d) building through light and inertial architecture.

All these requirements are related to thermal, respiratory, and lighting comfort. The principal challenge of the building in the tropical region is to avoid the overheating of the building envelope from the sun hence reducing the need for mechanical means of cooling. Houyoux knew that he could apply different techniques as stated by Devroey (1949): a) the orientation, from the actinometry or sunshine and of dominant wind point of view; b) the materials, mainly concerning their thermal properties and to the use of insulating; c) dimensions and the rational distribution of the rooms; d) the natural or artificial screens like trees, galleries, and verandas, canopies and louvres, curtains; e) the different ways of ventilation both horizontal and vertical.

Houyoux applied almost all these recommendations, looking after the conjoint parameters of the sun protection, of the ventilation, of the insulation, and the aesthetic. The architect had to build also the apartments for the Bank officers occupying the same site. In doing this he had to equally evolve an architecture adapted to the local context. 


\subsection{Dealing with the Sun Issues}

In handling the issues related to the sun and the heat gain associated with the building, he decided that the following considerations were important: 1) north-south orientation of the elevations; 2) the canopies; 3) the claustra; 4) the brise-soleil; 5) the perforated wall.

\subsubsection{North-south orientation of the elevations}

Regarding the spaces occupied permanently during the day, it is preferred to orient them north-south to benefit from the fresh wind. In placing an opening, he also foresaw a solution to protect it from sun's heating.

\subsubsection{The canopies}

Houyoux discovered that a perfect orientation might be difficult if the building was aligned to the road, hence the architect appeal to brise-soleil realizing many protrusions on the elevations called canopies. To obtain the best value he chose to locate based on the angle of incidence of the solar rays. The canopies are also a protection against the tropical rain, slightly inclined to the exterior, these elements enable water to fall without flowing along the façade, thus reducing the degradation due to humidity. To protect the glazed façade at the main elevation and to create a uniform exterior, he located a canopy that served as a gallery which is likened to the veranda in the villas. The architect is precisely placing the canopies of which the projection is calculated so as in all seasons, the equinoxes as the most unfavorable cases, the solar rays cannot touch the glazed surfaces (Houyoux-Diongre, 1954) as shown in Fig. 6 and Fig. 7. This horizontal element realizes a softed transition between the public road and the building's monumental mass.

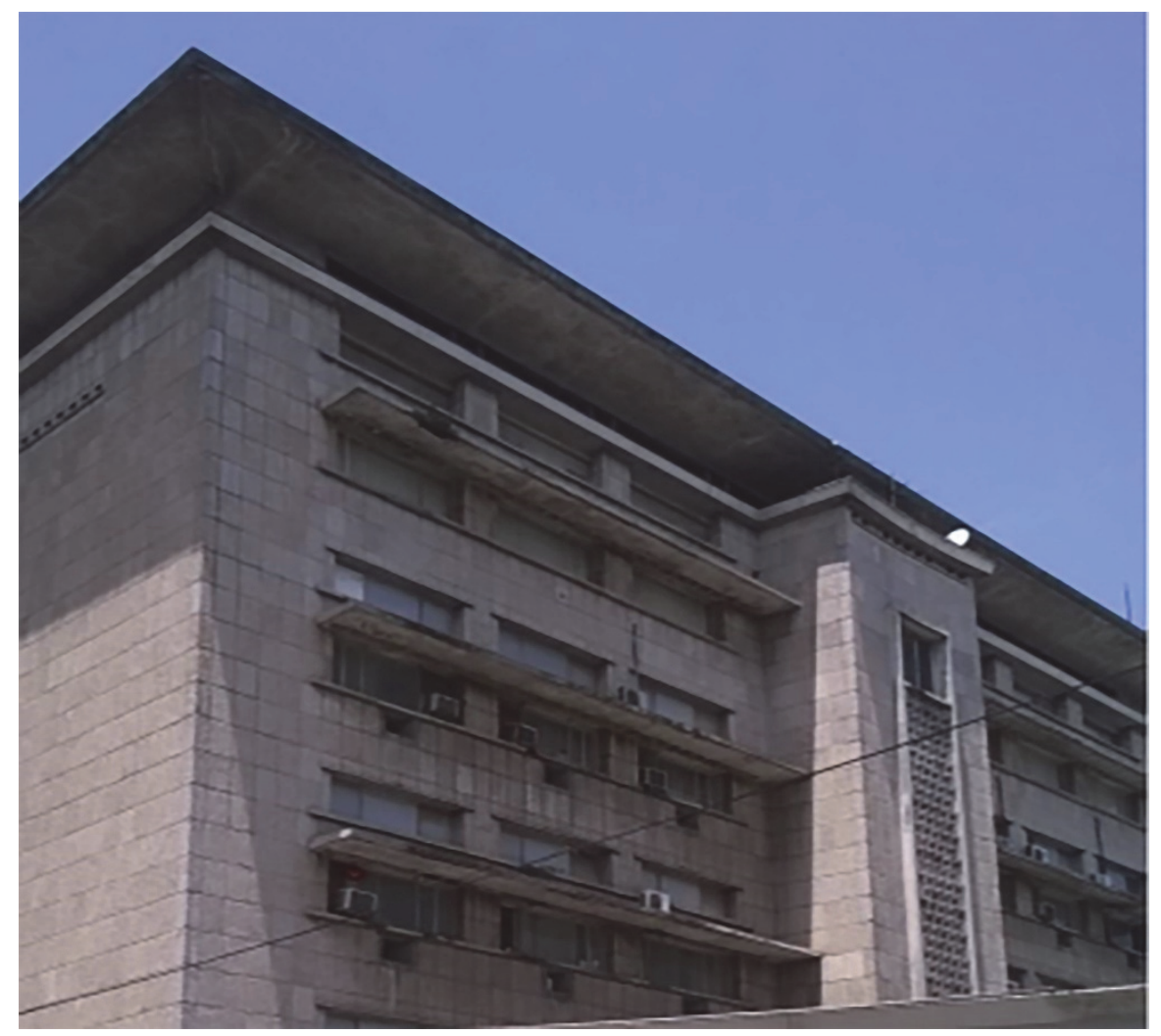

Figure 6. BCB building south elevation with overhanging slabs and lift ventilated trough claustras. Source: picture by Alexis Tshiunza (2016) 


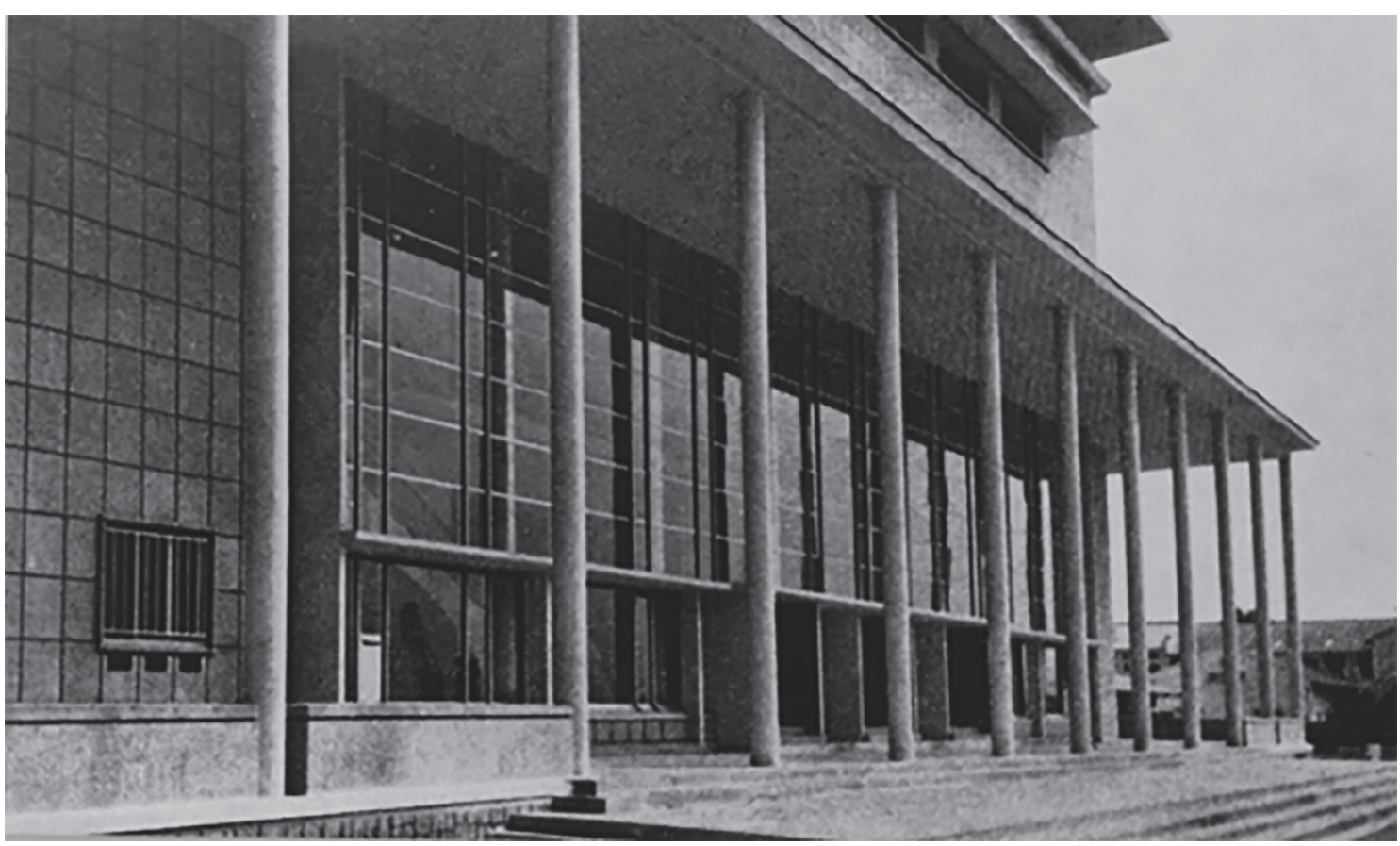

Figure 7. Canopy overlooking the glass façade. Source: Houyoux-Diongre (1954, p.18)

\subsubsection{The Claustra}

In circumstances where the canopies could not hide the sun or intercept the rays next to the vertical as related to rooms oriented East or West, it became necessary to have vertical sunshades placed inclined according to the angle of origin of the rays. Another opted solution is to placed claustra protruded from the window $50 \mathrm{~cm}$.

\subsubsection{The Brise-soleil}

The brise-soleil are designed to prevent them from heating the building because they were made of concrete, they were systematically placed in front of the terraces and not just in front of the windows. They are always painted white to keep the heat and reflect the light better and also inclined at 45 degrees to avoid reverberation of the radiation towards the apartments. A combination of the canopies, the claustra, and the strips obscure the sun and contribute to thermal and visual comfort. These elements take part in the decoration and bring a particular language of the tropical architecture. The goal of these terraces is to remind us that verandas are devices used for sun protection. They prevented the sun's rays from reaching directly the walls and especially the windows.

\subsubsection{The Perforated Wall}

Perforated walls are preferred on the facades most exposed to the sun. It consisted of raising two walls with an interior space for thermal insulation and adding a vacuum of 15 centimetres actively ventilated by a lower and upper air intake (Houyoux-Diongre, 1954). The outside wall that receives the heat during the day cannot transmit it inside even later by convection because the void serves as a barrier - see Fig. 3 and Fig. 6.

\subsection{The Ventilation Issues}

Ventilation is a key issue in any building design as this goes a long way in ensuring the health of the users and reduce the cost of mechanical means which would also determine the energy consumption of the building.

\subsubsection{The Transversal Ventilation}

The air circulation can be activated by the arrangement of the openings and their size. In principle, the openings must face each other and the one through which the air enters must be smaller than the outlet. It is mainly in the apartments that Houyoux applied the principle beloved by tropical modernism. The rooms overlook staggered terraces to optimize ventilation. Living rooms and dining rooms are in a continuum and their bays are on opposite sides as seen in Fig. 8. The service staircase is open but covered and allows a call of air for the internal circular staircase (Houyoux-Diongre, 1949). 


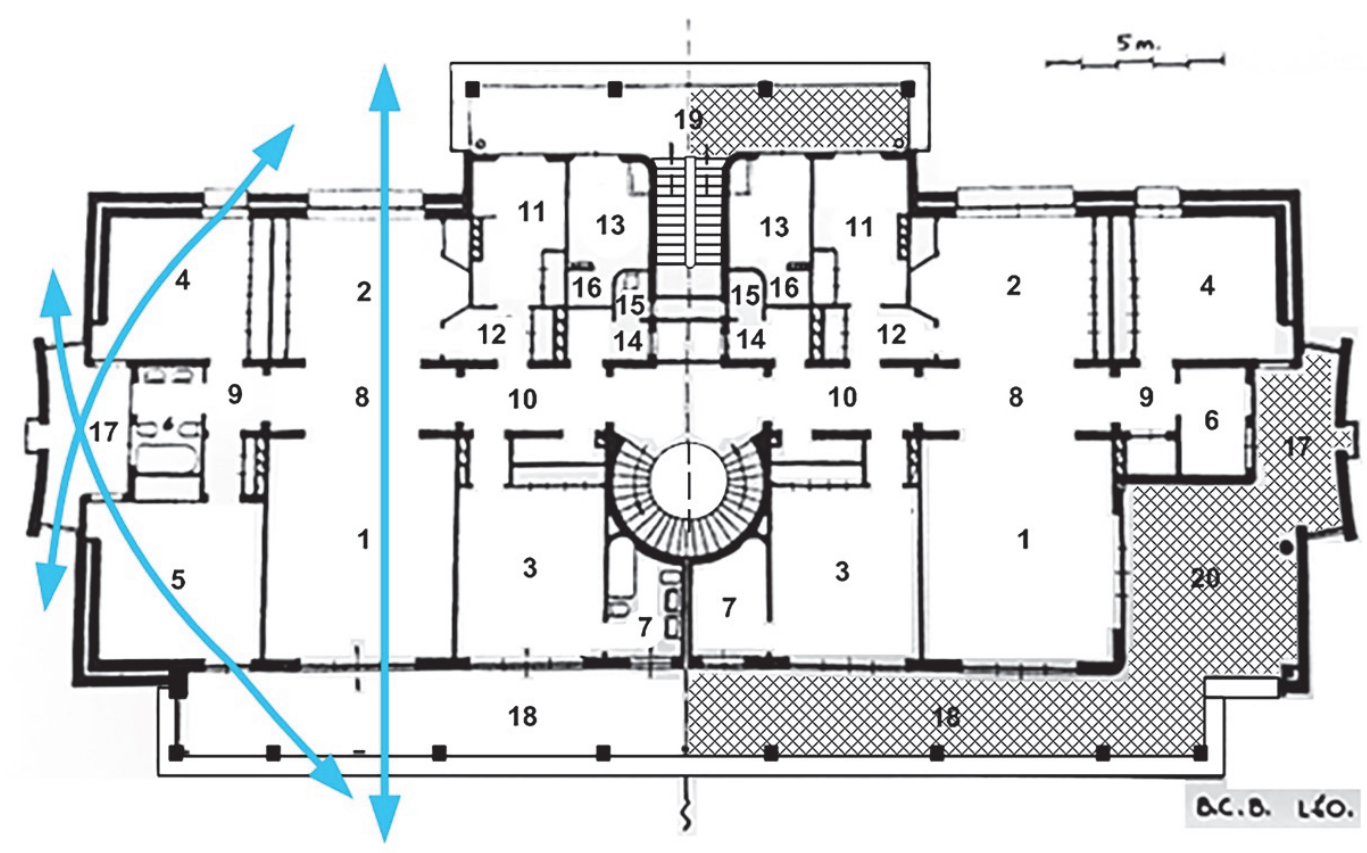

Figure 8. Plan view apartments building. Legend: 1. Living room; 2. Dining room; 3.-4.-5. Bedrooms; 6.-7. Bathrooms; 8. Corridor; 9. Passage; 10. Vestibule; 11. Kitchen; 12. Office; 13. Maiden room; 14.-15. Toilettes; 16. Shower maiden; 17.-18.-19.-20. Terraces; 19. Service terrace. Source: Houyoux-Diongre (1950, p.21)

\subsubsection{The Chimney Effect}

A large tellers' hall is located at the centre and it is left empty on the whole height of the building. To properly ventilate it, he adds a small roof like a lantern above this central void. Sunshades are placed there and left open enough to facilitate natural ventilation. When hot air rises and escapes, the space is refreshed (Houyoux-Diongre, 1954). The chimney effect or static ventilation is very important because one cannot always count on the wind. Creating a difference in density between hot air and cold air to activate ventilation became a solution (Dequeker \& Kanene, 1992).

\subsubsection{The Parasol Roof}

An overflowing roof appeared as a parasol to better protect the building. To perform this function and role of an umbrella, it needed ventilation below. In Fig. 9, is recognizable a double roof with a ventilated void of a dimension ranging from 90 to 100 centimeters the roof thus benefitted from cross ventilation. When there is a gap between the roof and the false ceiling, the interior of the room below is cooled by limiting the heat input. The slats are placed in front of the terraces and also around the lantern of the roof to facilitate ventilation. 


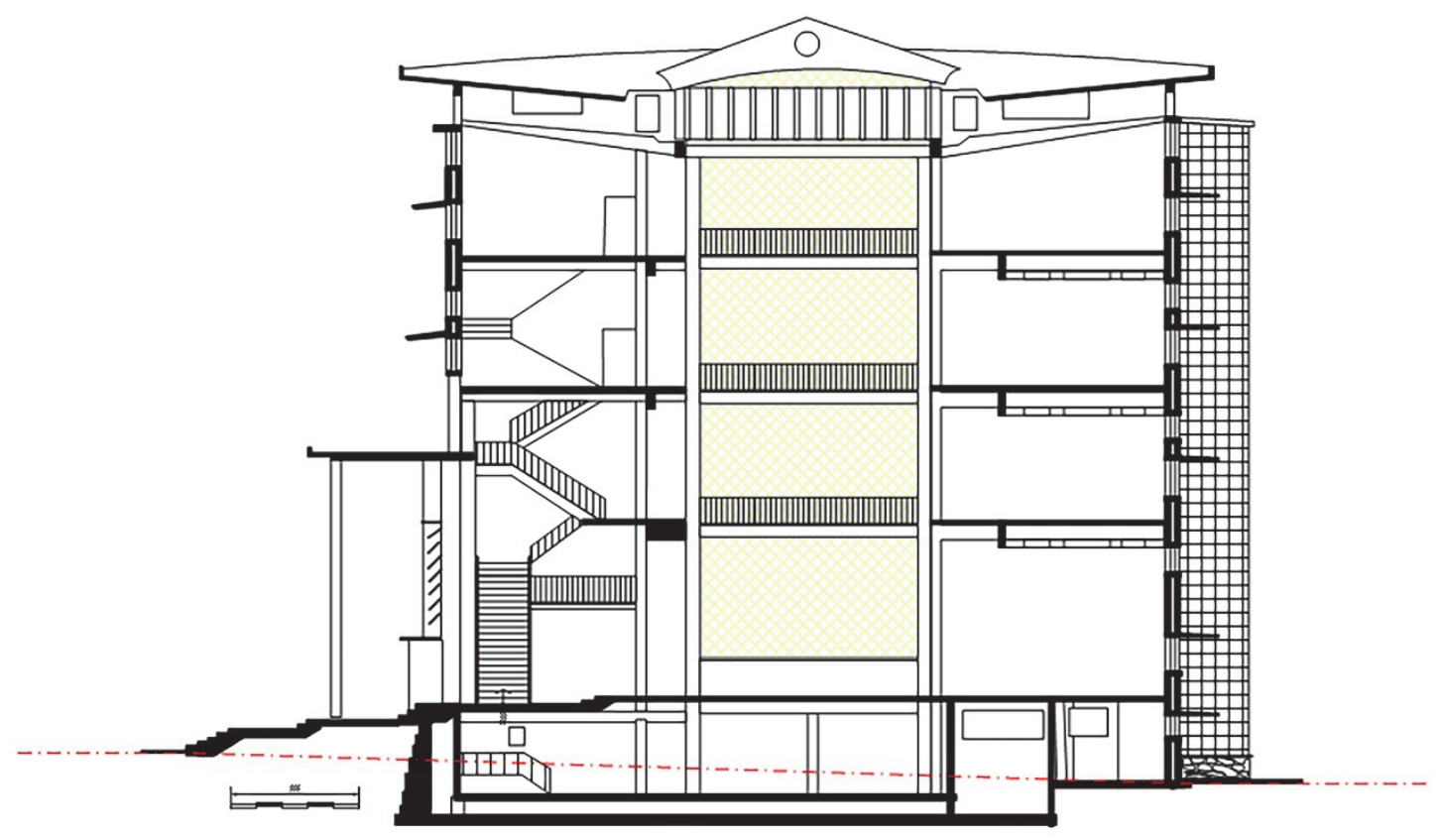

Figure 9. Parasol roof with sun-breakers and central hall. Source: drawing by Alexis Tshiunza

\subsubsection{The Distance between Buildings}

Constructing in the same compound with several buildings, as previously said, was a challenge for the ventilation. Buildings can indeed become screens (barriers) for each other. It takes at least 25 times the height of the screen or obstacle building for the full wind speed to recover, which is almost impossible in a city center. To maintain good ventilation anyway, it takes a distance between buildings of at least three times the height of the obstacle in Fig. 10 as will be later described also by Dequeker and Kanene (1992). This standard has been taken into account and combined both the height of the buildings and the distance between them to maintain a good ratio.

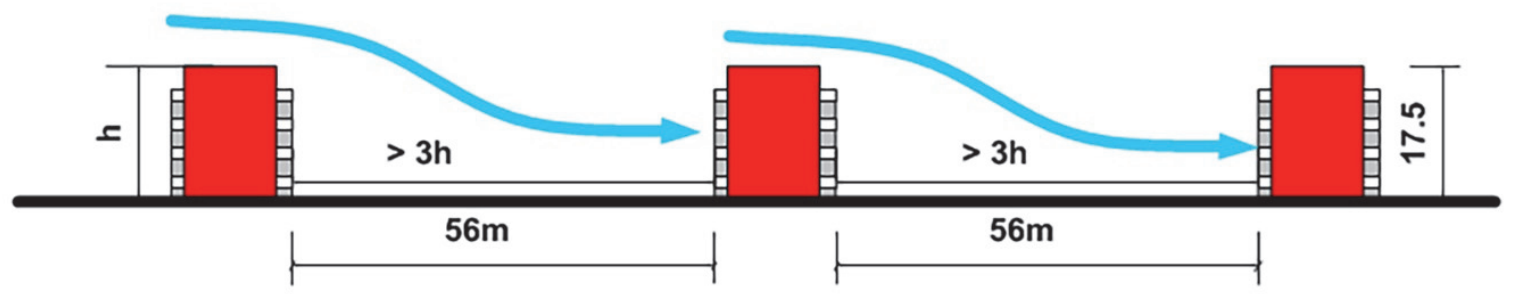

Figure 10. Ventilation between BCB apartment-buildings. Source: drawing by Alexis Tshiunza

\subsection{The Building Envelope}

\subsubsection{The Elevations}

The elevations were usually made of bricks with inner cavities, which added more insulation. The bricks used for the construction of the Bank were naturally manufactured in Congo, mostly bricks and concrete. It was not a problem in the late 40s because bricks had been used in the Congo since the beginning of the 20th century by missionaries as well as the implantation of the first cement factories such as Cements du Congo (1920) or Cements du Katanga (1922), (Craenenbroeck, 2015).

\subsubsection{Adverse Events}

"The exterior walls are covered with crushed white quartz concrete slabs from the region" (Houyoux-Diongre, 1954), which gave the building a local touch. They planned to make these slabs on site because they were found 
close to the river. The choice of quartz was because it was considered a good material that does not deteriorate over time and also protected the building very well from tropical rains. Therefore, this choice is a very good thing in sustainability in addition to being a local material. It is white and thus reflects the sun's rays better, reducing overheating and it does not require much maintenance because it does not pick up dust, which is removed with the first rain or wind. The buildings were white and preferably covered concrete slabs inlaid with quartz chips that became a feature of tropical modernism in Leopoldville (Lagae et al., 2013). While many will limit the use of quartz concrete slabs to the exterior cladding of facades, Houyoux found it useful to replace the pavements and steps made of stone of France shaped in Belgium with quartz (Houyoux 1949). While the architect had worked hard to make a building whose exterior is almost in all respects local, some finishing materials are nevertheless imported because they were not produced on-site, thus, the parapets are in Ticino granite (Houyoux-Diongre, 1954). The facing of the halls is in the travertine of Morocco and the walls of the hall are covered with Norway green marble - see Fig. 11. It was normal and even though the cladding was not the same for the interior walls. The architect married this green tone with the white enamel that he also applied to the columns facing the main entrance in Fig. 3 and Fig. 14 (Houyoux-Diongre, 1954).

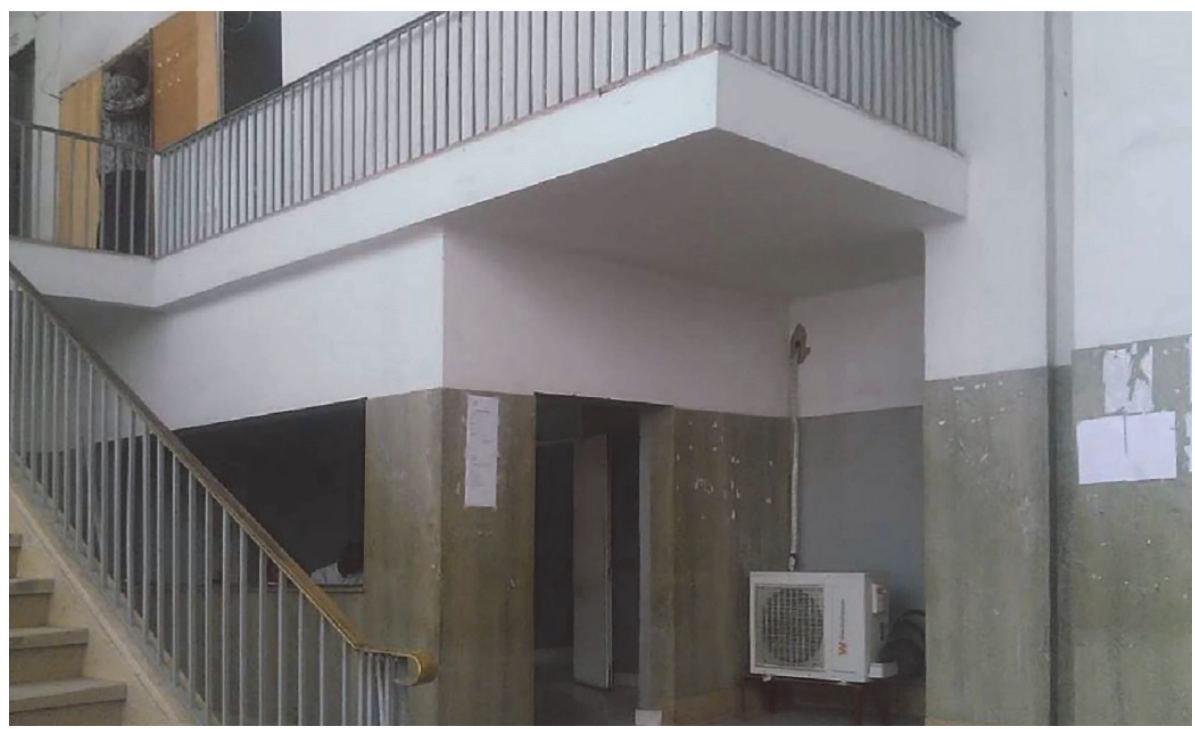

Figure 11. Imported green upholstery for the grand hall. Source: picture by Alexis Tshiunza (2016)

\subsection{The Colors}

It has been noticed the use of bright and vivid colors to contrast with the light sifted by the layer of cloud that almost always floats at a low level in the neighboring area of the equator. The two twin buildings were painted in Basque red for the back parts, cerulean blue or deep ochre for shade-free canopies, and pure white gloss for the freestanding columns.

\subsection{Contextualization}

None of the young architects who came to Congo thought of simply copying and pasting. Each bank that Houyoux designed has kept its originality, although the typology and language of the architect can be recognized. The headquarters of the bank in Stanleyville -depicted in Fig. 12 and Fig. 13, is different from that of Kinshasa, but we can recognize common traits or obvious kinship, in the mass, in the materials, in the details. Here, although there are large windows, the awnings are less pronounced because the sun near the equator seldom touches the north and south facades. The arcuate shape of the lower volume of the main façade would also meet a visual requirement of the site (Houyoux-Diongre, 1950). 


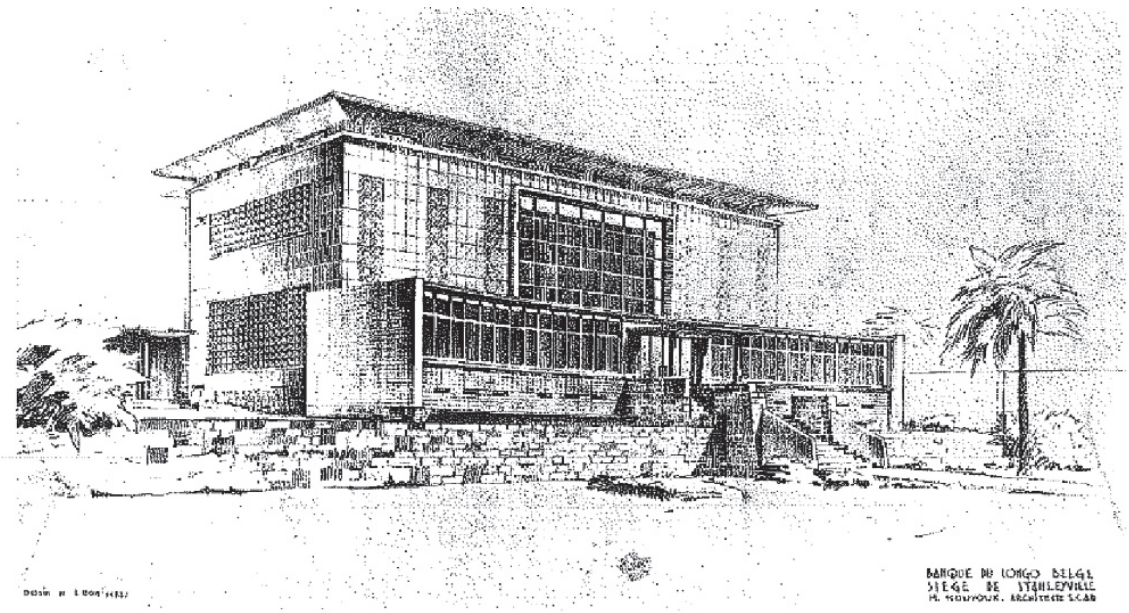

Immeuble pour la banque du Congo belge à Stanleyville (Congu), 1948-1958.

Figure 12. Perspective view BCB Headquarters in Stanleyville. Source: Houyoux-Diongre (1950, p.21)

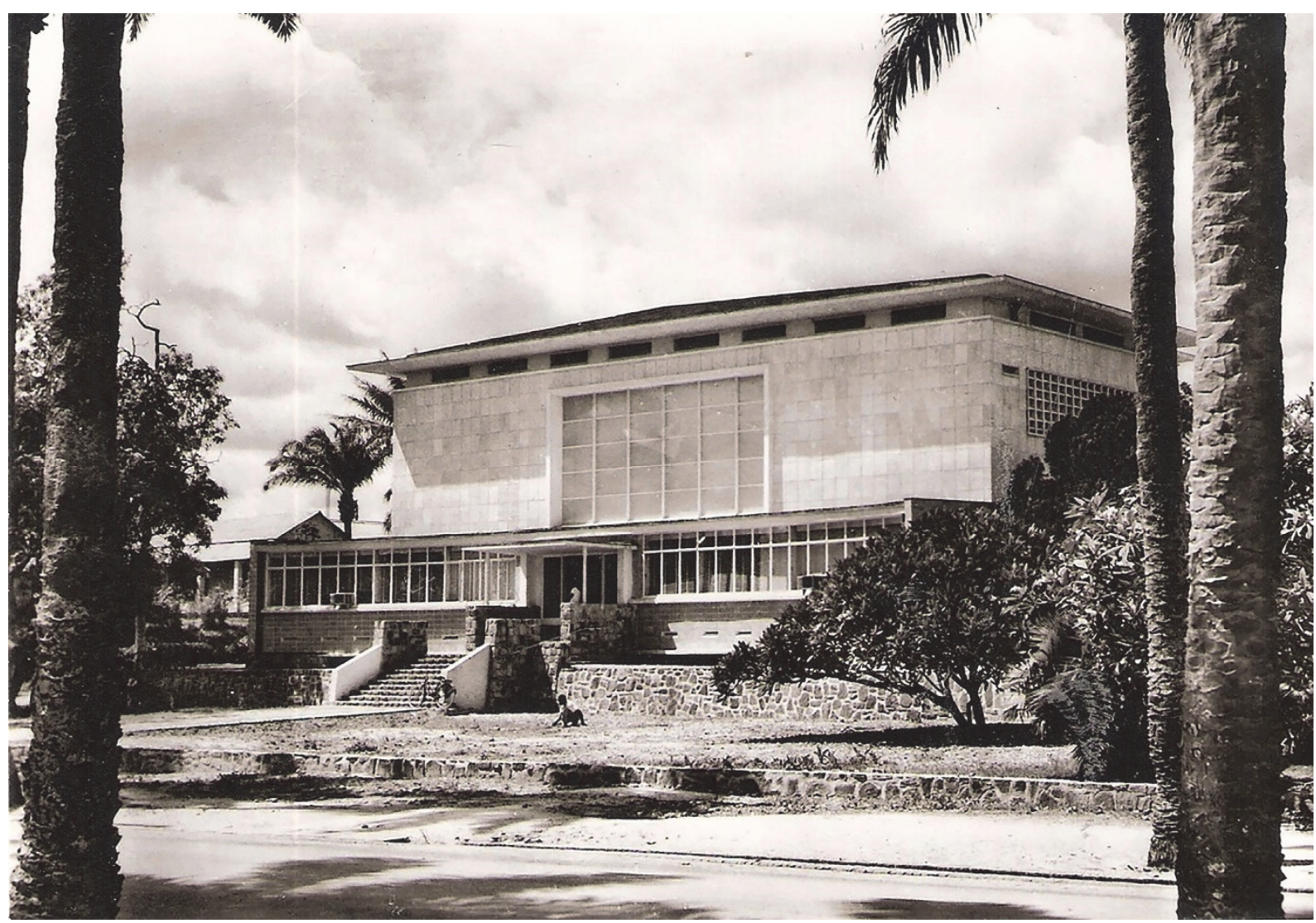

Figure 13. BCB Headquarters in Stanleyville. Source: www.delcampe.be

\section{The Real Tradition}

Maurice Houyoux did not have the "concern to do as in Belgium" (Houyoux-Diongre, 1950) striving to showcase modern but African architecture. Provided that the state favors appropriate urban planning, its "architecture thrives there at ease in a form well adapted to technical and aesthetic requirements, fleeing false regionalism" (Puttemans, 1960). To detect it, a careful study of atavisms is necessary, a careful comparison of the movements of the past and nowadays (Bidart, 2007). Explaining his inspiration and the parameters that allowed him to realize buildings appreciated in the tropics, Maurice Houyoux says that the only merit is to have brought to light those rules of 
which the old colonial-style had been able to suit the context. The peoples of hot countries have known these imperatives since always and in their way of building, have always complied" (Houyoux-Diongre, 1955)

The tradition of the peoples of the warm countries is first and foremost a response to the climate. The architecture that the black builders spontaneously practice is in the image of the African life of the tropics, closely subject to the imperatives of nature and climate. By responding to climates and observing the practices of indigenous peoples, architects called to work in the Congo expected to develop an architecture appropriate to the environment. The technical solutions Houyoux proposed, even used with different materials, allow to find the common links with the basic parameters and to get closer to vernacular architecture: Correct orientation, almost blind facades, awning, and natural ventilation.

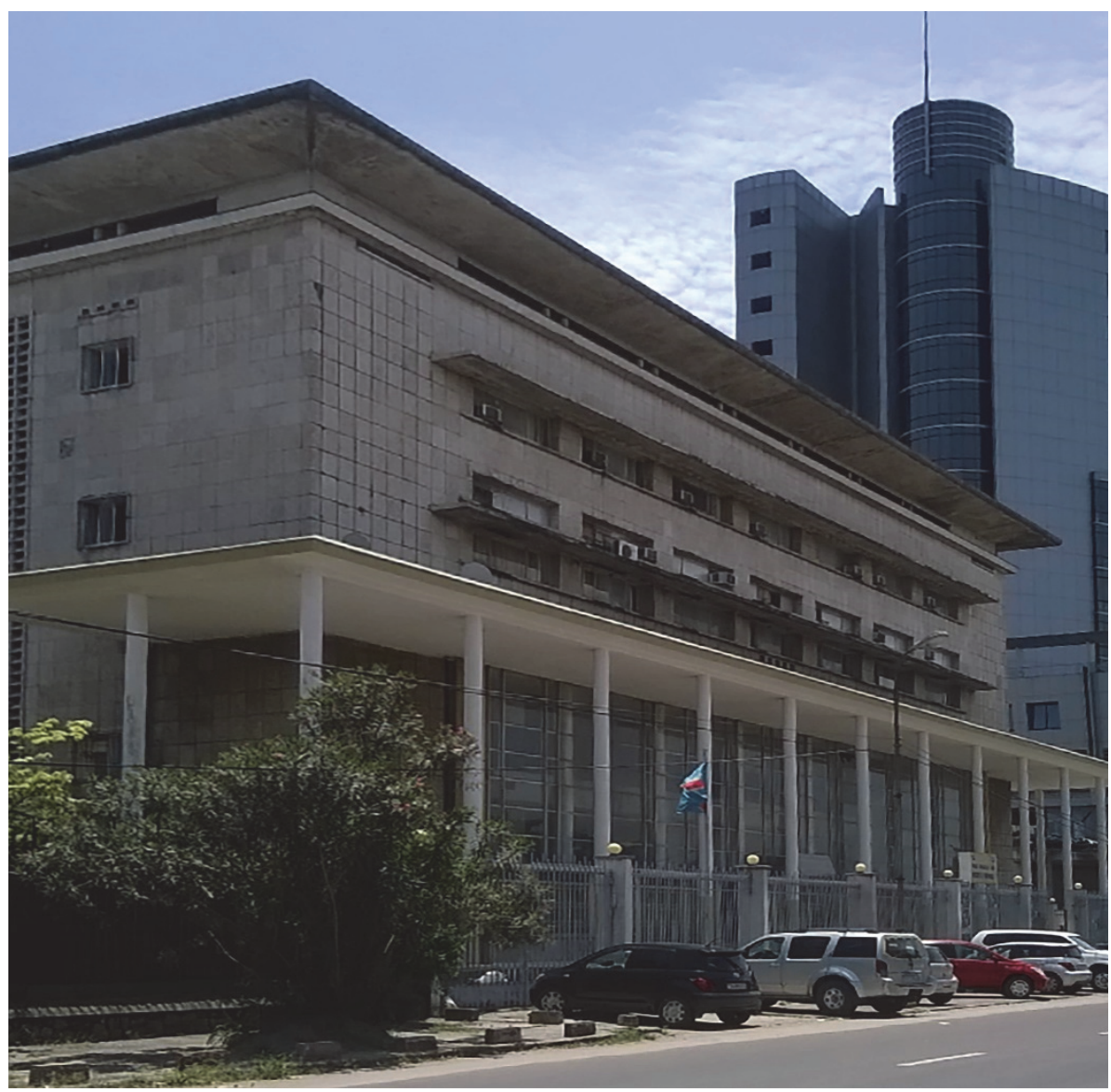

Figure 14. Congo Belge Bank. Source: picture by Alexis Tshiunza (2016)

\section{Conclusions}

By observing the achievements and principles applied to build in hot countries, Maurice Houyoux realizes that there are parameters that have always guided construction in the tropics. Based on this, the modernist architects took the same referents, the same institutions as the traditional builders, and the logical consequence, was to be a certain kinship referred to as true regionalism. The fact of not copying a vernacular architecture or a culture does not exclude that in the end there are elements of it even if the approach of the design is the same. The constructive traditions seem to have something in common: Respect of the imperatives of the climate and the use of the local materials. Puttemans Robert thinks that the example that the best Belgian achievements left in Kinshasa can save the country from trial and error if it understands its significance. Maurice Houyoux, unfortunately, died shortly before Congo's independence. It was observed from the study that even though there was no documented data for Houyoux to work with during the time design buildings in Congo, he was able to examine the design consideration from the traditional builders to develop design parameters. His design decisions ensured that the bank headquarters was a good fit for the environment and that the users were comfortable. The design decisions also ensured that through his designs he was able to evolve the architecture of the people that were already existing though not pronounced. A key finding from the study showed that Houyoux avoided the temptation of copying and pasting 
designs which would have saved him time rather he opted to develop to fit the culture and tradition of the people.

\section{References}

Atkinson, C. M. (1950). Construire sous les tropiques. Rythme, 8, 33-45.

Bidart, P. (2007). La production des néo-styles régionaux. Ethnologie française, 37, 35-38. https://doi.org/10.3917/ethn.070.0035.

Catalgirone, S. (2010). Maurice Houyoux sous les tropiques. Les nouvelles du patrimoine, 128, 27-29.

Craenenbroeck, L. (2015). Een Belgisch bouwbedrijf in Congo: de familie Blaton als Compagnie Congolaise de Constructions en als Congobéton van 1949 tot 1975, University of Gent, Gent.

Dequeker, P., \& Kanene, M. (1992). L'architecture tropicale, théorie et mise en pratique en Afrique tropicale humide. Kinshasa, DR Congo: Centre de Recherches Pédagogiques.

Devroey, E. J (1949). Conditions de vie et facteurs physiques auxquels doivent répondre les habitations au Congo belge. Rythme, 6, 13-14.

Houyoux-Diongre, M. (1949). Siège de la Banque du Congo belge à Léopoldville \& immeubles à appartements. Rythme, 6, 24-26.

Houyoux-Diongre, M. (1950). Architectes Belges au Congo, immeubles d'appartment. Rythme, 8, 20-22.

Houyoux-Diongre, M. (1954). Trois sièges de la Banque du Congo Belge à Léopoldville, Bukavu, Stanleyville. Rythme, 17, 18-21.

Houyoux-Diongre, M. (1955). Grandeurs et servitudes de l'architecture en pays tropicaux. Une interview avec M. Houyoux-Diongre. Objectif, 9, 8-15.

Houyoux-Diongre, M. (1956). Architecture et urbanisme au Congo. La Revue Coloniale Belge, 262, 893-895.

Jungers, E. (1950), Message de Monsieur E. Jungers, Gouverneur Général du Congo Belge. Rythme, 8, 3.

Lagae, J., \& Toulier, B. (2013). Kinshasa. Bruxelles, Belgium: CIVA.

Lagae, J., \& Craenenbroeck, L. (2015). Congobéton Léopoldville. Congés payés du 1/1/57 au 31/12/57: Postwar Architecture, Construction Work and Local Labor in a Belgian Colony. ABE Journal, 8. https://doi.org/10.4000/abe.2797

Lecocq, P., \& Robert, Y. (2012). Kinshasa (Architectural guide). Bruxelles, Belgium: Université libre de Bruxelles.

Loo, C. (1949). Protections contre les rayons solaires. Rythme, 6, 18-20.

Puttemans, R. (1960). Editorial. Rythme, 31, 2.

Ricquier, G. (1950). Urbanisme au Congo Belge. Bruxelles, Belgium: De Visscher.

Scaillon, E. (1959). Le centre culturel et le climat de Léopoldville. Rythme, 29, 22-23.

Vanhove, J. (1968). Histoire du ministère des colonies. Bruxelles, Belgium: Académie Royale des Sciences d'Outre-Mer, Classe des Sciences morales et politiques.

Vogler, C. (1950). Congo 1950. Rythme, 8, 11.

\section{Copyrights}

Copyright for this article is retained by the author(s), with first publication rights granted to the journal.

This is an open-access article distributed under the terms and conditions of the Creative Commons Attribution license (http://creativecommons.org/licenses/by/4.0/). 